Article

\title{
Erylusamides: Novel Atypical Glycolipids from Erylus cf. deficiens
}

\author{
Helena Gaspar 1,2,*, Adele Cutignano ${ }^{3}$, Laura Grauso ${ }^{3}$, Nuno Neng ${ }^{1}$, Vasco Cachatra ${ }^{1}$, \\ Angelo Fontana ${ }^{3}$, Joana Xavier ${ }^{4}$, Marta Cerejo ${ }^{5}$, Helena Vieira ${ }^{6}$ and Susana Santos ${ }^{1, *}$ \\ 1 Centro de Química e Bioquímica (CQB), Departamento de Química e Bioquímica, Faculdade de Ciências, \\ Universidade de Lisboa, Campo Grande, Lisboa 1749-016, Portugal; ndneng@ciencias.ulisboa.pt (N.N.); \\ vasco_cachatra@hotmail.com (V.C.) \\ 2 MARE-Centro de Ciências do Mar e do Ambiente, Faculdade de Ciências, Universidade de Lisboa, \\ Campo Grande, Lisboa 1749-016, Portugal \\ 3 CNR-Istituto di Chimica Biomolecolare, Bio-Organic Chemistry Unit, via Campi Flegrei 34, \\ Pozzuoli (NA) 80078, Italy; acutignano@icb.cnr.it (A.C.); laura.grauso@icb.cnr.it (L.G.); \\ afontana@icb.cnr.it (A.F.) \\ 4 Department of Biology and Centre for Geobiology, University of Bergen, P.O. Box 7803, Bergen N-5020, \\ Norway; joana.xavier@bio.uib.no \\ 5 Research \& Innovation Accelerator, Faculdade de Ciências e Tecnologia, Universidade Nova de Lisboa, \\ Campus de Caparica, Caparica 2829-516, Portugal; m.cerejo@fct.unl.pt \\ 6 BioISI, Instituto de Biociências e Ciências Integrativas, Faculdade de Ciências, Universidade de Lisboa, \\ Campo Grande, Lisboa 1749-016, Portugal; hmvieira@ciencias.ulisboa.pt \\ * Correspondence: hmgaspar@ciencias.ulisboa.pt (H.G.); smsantos@ciencias.ulisboa.pt (S.S.); \\ Tel.: +351-217500563 (H.G.); +351-217500948 (S.S.)
}

Academic Editor: Danielle Skropeta

Received: 11 July 2016; Accepted: 15 September 2016; Published: 11 October 2016

\begin{abstract}
Among marine organisms, sponges are the richest sources of pharmacologically-active compounds. Stemming from a previous lead discovery program that gathered a comprehensive library of organic extracts of marine sponges from the off-shore region of Portugal, crude extracts of Erylus cf. deficiens collected in the Gorringe Bank (Atlantic Ocean) were tested in the innovative high throughput screening (HTS) assay for inhibitors of indoleamine 2,3-dioxygenase (IDO) and showed activity. Bioassay guided fractionation of the dichloromethane extract led to the isolation of four new glycolipids, named erylusamide A-D. The structures of the isolated compounds were established by 1D and 2D nuclear magnetic resonance (NMR) spectroscopy, high-resolution electrospray ionization mass spectrometry (HR-ESI-MS) and chemical derivatization. The metabolites shared a pentasaccharide moiety constituted by unusual highly acetylated D-glucose moieties as well as D-xylose and D-galactose. The aglycones were unprecedented long chain dihydroxyketo amides. Erylusamides A, B and $\mathbf{D}$ differ in the length of the hydrocarbon chain, while erylusamide $\mathbf{C}$ is a structural isomer of erylusamide $\mathbf{B}$.
\end{abstract}

Keywords: Erylus; indoleamine 2,3 dioxygenase; glycolipids; marine natural products; sponges; anti-cancer; erylusamides

\section{Introduction}

The secondary metabolites found in marine invertebrates represent a rich source of novel chemical diversity for lead compounds, with sponges being the most prolific source of new molecules. Between these structurally unique metabolites, glycolipids play an important role. Glycolipids belong to the broad class of glycoconjugates and are characterized by having one or more monosaccharide residues linked by a glycosidic bond to a hydrophobic moiety, such as an acylglycerol, a sphingoid, 
or a prenyl phosphate [1]. Glycolipids, including glycosphingolipids and gangliosides, are widely found in marine invertebrates, especially in echinoderms (sea stars, sea cucumbers) and sponges, and show a large variety of biological activities such as antitumor, immunomodulatory and nitric oxide release-inhibiting activities [2].

Sponges of the genus Erylus Gray, 1867 (Tetractinellida, Geodiidae) were reported to produce uncommon phospholipid methyl branched fatty and unusual glycolipids, some of which have interesting pharmacological activities, such as anticancer and interleukin-6 (IL-6) receptor antagonists (Table 1). The same type of glycolipids found in Pachymatisma johnstonias, a species that belongs to the same family of Erylus, showed inhibitory activity of bacterial type III secretion [3].

Table 1. Glycolipid and lipid content of Erylus and Pachymatisma species.

\begin{tabular}{|c|c|c|}
\hline Sponge/Origin & \multicolumn{2}{|c|}{$\begin{array}{c}\text { Compounds } \\
\end{array}$} \\
\hline $\begin{array}{c}\text { Erylus formosus } \\
\text { La Parguera, } \\
\text { Puerto Rico [4] }\end{array}$ & $\begin{array}{l}\text { Fatty acid: } \\
\text { Tetradecanoic } \\
\text { 13-Methyltetradecanoic } \\
\text { 12-Methyltetradecanoic } \\
\text { 3-Methylpentadecanoic } \\
\text { Hexadecenoic } \\
\text { Methylpentadecanoic } \\
\text { Hexadecanoic } \\
\text { 3-Methylhexadecanoic } \\
\text { 15-Methylhexadecanoic } \\
\text { 14-Methylhexadecanoic } \\
\text { 5,9-Octadecadienoic } \\
\text { Octadecenoic } \\
\text { Octadecanoic } \\
\text {--_- - - - - - - - - - - - - }\end{array}$ & $\begin{array}{l}\text { Methyloctadecanoic } \\
\text { 5,9-Icosadienoic } \\
\text { 19-Methyl-5,9-icosadienoic } \\
\text { 18-Methyl-5,9-icosadienoic } \\
\text { Heneicosanoic } \\
\text { Tricosanoic } \\
\text { Tetracosanoic } \\
\text { Pentacosanoic } \\
\text { 24-Methyl-5,9-pentacosadienoic } \\
\text { 5,9-Hexacosadienoic } \\
\text { 25-Methyl-5,9-hexacosadienoic } \\
\text { 24-Methyl-5,9-hexacosadienoic } \\
\text { 5,9-Octacosadienoic } \\
\text { 5,9-Nonacosadienoic } \\
\quad \text { NR }\end{array}$ \\
\hline
\end{tabular}


Table 1. Cont.

\begin{tabular}{|c|c|}
\hline Sponge/Origin & 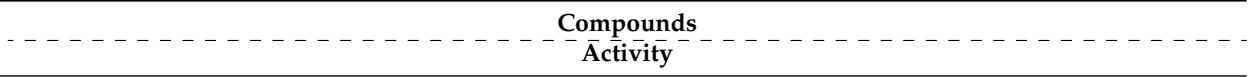 \\
\hline $\begin{array}{l}\text { Erylus placenta } \\
\text { Hachijojima Island } \\
\quad \text { (Japan) [6,7] }\end{array}$ &  \\
\hline $\begin{array}{l}\text { Erylus cf. Lendenfeidi } \\
\text { Gulf of Eilat } \\
\text { (Red sea) [8] }\end{array}$ & 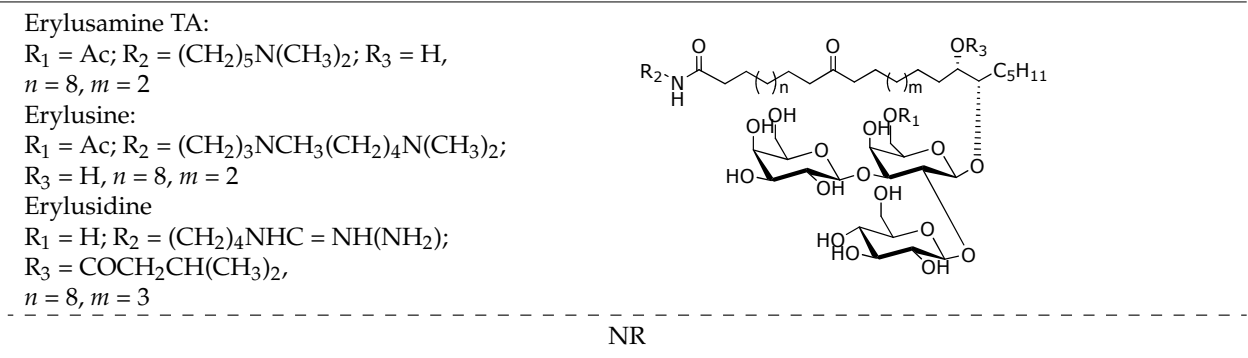 \\
\hline $\begin{array}{l}\text { Erylus trisphaerus } \\
\text { Dominica [9] }\end{array}$ & Trisphaerolide \\
\hline $\begin{array}{l}\text { Pachymatisma } \\
\text { johnstonia Isle of } \\
\text { Mann (UK) [3] }\end{array}$ & Pachymoside A \\
\hline
\end{tabular}

Indoleamine 2,3-dioxygenase (IDO1), formerly known as IDO before the discovery of a second isoform, is the first and rate-limiting enzyme in the oxidative degradation of the essential amino acid tryptophan through the kynurenine pathway and plays a role in the control of infection and in evasion of T-cell-mediated immune rejection [10]. It is believed that IDO1 inhibits the proliferation and differentiation of $\mathrm{T}$ cells, which are sensitive to the degradation of tryptophan and accumulation of its catabolites. IDO1 is overexpressed in a variety of tumor cell types and acts against the T-cell attack, thus facilitating the growth and survival of malignant cells [11]. For these reasons, IDO1 has emerged as a key target in cancer immunotherapy. Several inhibitors have been synthesized and proved to be efficient, alone or in combination with other therapeutics. However, by 2014, the pipeline of IDO inhibitors comprised only four drug candidates: indoximod, epacadostat, NLG919 and an IDO derived peptide [12]. Indoximod (D-1-methyl-tryptophan) is being tested in combination with other drugs in several phase I and II clinical trials. Epacadostat (INCB024360), an hydroxyamidine that targets and binds to IDO1 is now in several phase I and II clinical trials [13]. NLG919 is an imidazoleisoindole derivative undergoing phase I clinical trials in the treatment of recurrent advanced solid tumors alone or in combination with other drugs. After the human IDO1 structure was determined by X-ray crystallography in 2006, several synthetic inhibitors were developed based on the structure of the active-site [14]; however, to the best of our knowledge, no comprehensive screening of compounds (or extracts) from marine origin was ever undertaken.

With that background in view, in a previous project, we have undertaken a comprehensive screening of crude extracts of sponges from the Portuguese coast using the Blockade application of GPS D ${ }^{2}$ High Throughput Screening (HTS) system that uses the human version of indoleamine 2,3-dioxygenase 1 (IDO1) as therapeutic target [15]. This paper describes the isolation and structure 
determination of four new glycolipids, named erylusamides A-D, compounds 1-4 (Figure 1), found in the IDO's inhibitor organic extract of Erylus cf. deficiens Topsent, 1927.

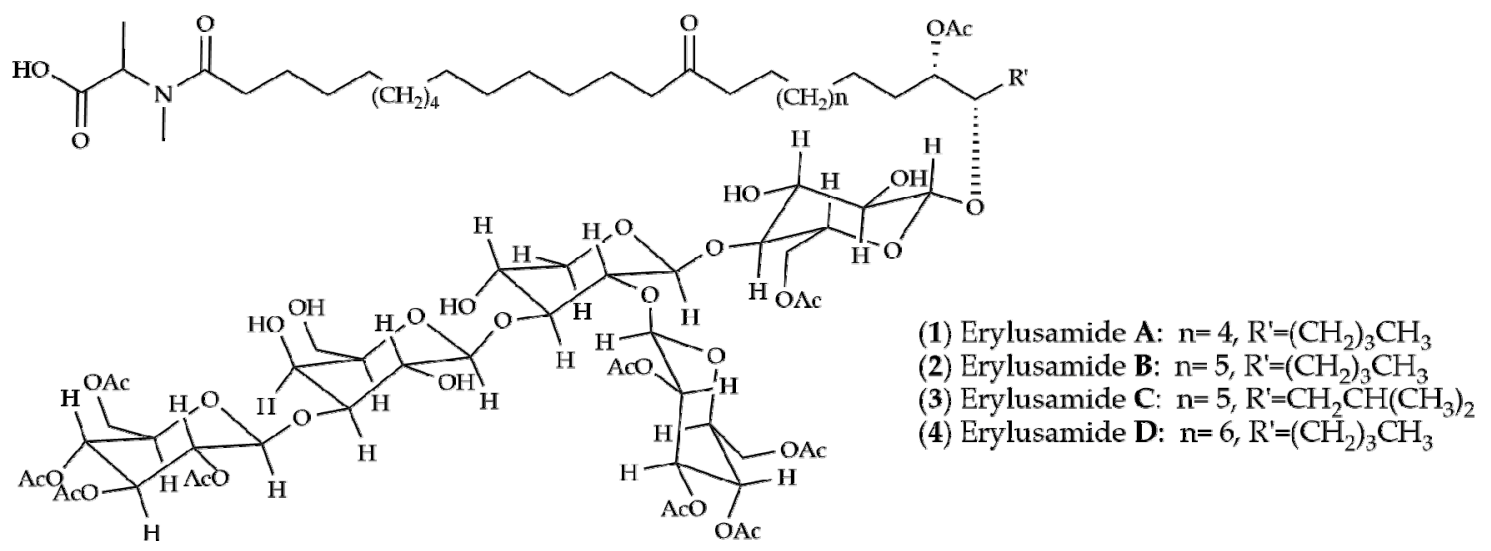

Figure 1. Structures of erylusamides A-D.

\section{Results and Discussion}

Within the scope of a previous drug discovery campaign, a comprehensive library of 185 organic extracts of sponge specimens collected in several off-shore Portuguese locations (Berlengas, Azores and Gorringe bank) was constructed. The extracts were screened as modulators of proteins involved in cancer and neurodegenerative diseases using the Global Platform Screening for Drug Discovery (GPS D2) technology developed by the Portuguese biotech company BIOALVO (Lisbon, Portugal), which uses modified Saccharomyces cerevisiae strains designed to express specific targets involved in diseases with a tremendous social and economic burden. BIOALVO's BLOCKADE application, which targets compounds able to inhibit the enzyme indoleamine 2,3 dioxygenase (IDO-1), was selected to first test the extracts. Extracts were considered positive if they inhibited the growth of BLOCKADE yeast $>60 \%$ [15]. In the BLOCKADE screening, the dichloromethane extract of the marine sponge Erylus cf. deficiens collected in the Gorringe Bank (Atlantic Ocean) tested positive at a concentration of $0.125 \mathrm{mg} / \mathrm{mL}$. The activity of this extract was confirmed using an additional assay with African green monkey kidney fibroblast COS7 cells transfected with IDO, revealing an IDO inhibitory activity of $80 \%$. The organic extract was further separated by flash chromatography on C18 reverse phase silica gel (RP-18) into eleven fractions, one of which (fraction 2) conserved the activity of the original extract, inhibiting kynurenine production by $80 \%$ at the same concentration.

${ }^{1} \mathrm{H}$ nuclear magnetic resonance (NMR) spectrum of fraction $2(150 \mathrm{mg})$ revealed complex signals belonging to sugar components between $\delta 6.4$ and $3.5 \mathrm{ppm}$, together with aliphatic resonances, due to a lipid moiety in the upfield region of the spectrum, thus suggesting the occurrence of a series of glycoconjugates. Hence, as a first step in the structure elucidation of the bioactive components, a methanolysis reaction was performed on an aliquot of the mixture to liberate the aglycone from the monosaccharide pool. Methyl glycosides were converted into the corresponding trimethylsilyl (TMS) derivatives [16] and analysed by GC-MS in comparison with authentic standards. According to retention time and characteristic MS fragmentation patterns, monosaccharide units were identified as D-xylose, D-glucose and D-galactose. On the other hand, aglycones showed IR bands at 3349, 1740, 1701 and $1636 \mathrm{~cm}^{-1}$, suggesting the presence of hydroxyl, ester, ketone and amide functionalities, which were confirmed by NMR data. Separation of individual components was achieved by RP-HPLC on a phenyl-hexyl column (Phenomenex) affording 1-4 (Figure 1), as pure compounds, here named erylusamides A-D. High-resolution electrospray ionization mass spectrometry (HR-ESI-MS) analysis in negative ionization polarity revealed that compounds 1-4 constituted a series of homologous compounds displaying molecular mass ions at $m / z$ 1782.8345, 1796.8515, 1796.8434 and 180.8644 . 
Erylusamide A (1) gave a molecular ion $[\mathrm{M}-\mathrm{H}]^{-}$at $m / z$ 1782.8345, which accounts for the molecular formula $\mathrm{C}_{83} \mathrm{H}_{133} \mathrm{NO}_{40}$ requiring 18 degrees of formal unsaturation. 1D and 2D-NMR data (Tables 2 and 3) revealed diagnostic signals of an oligosaccharide moiety composed of five sugar residues, and of a polyketide aglycone displaying three carbonyl signals at $\delta 210.5,174.9$ and $173.2 \mathrm{ppm}$ in the ${ }^{13} \mathrm{C}$ NMR spectrum. Several different spin systems were identified in the aglycone moiety through COSY and HSQC-TOCSY connectivities, and joined by HMBC correlations (Figure 2). In particular, one terminal end of the aglycone polyketide chain was assigned to a $N$-methylalanine substructure. In fact, a deshielded signal at $\delta 5.75\left(\mathrm{H}-2^{\prime}, \mathrm{q}\right)$ was coupled in the COSY spectra with a methyl doublet at $\delta 1.54\left(\mathrm{H}_{3}-4^{\prime}\right)$, as well as in the HMBC spectra, and showed correlations with a carboxyl function at $\delta 174.9 \mathrm{ppm}\left(\mathrm{C}-1^{\prime}\right)$ and a methyl carbon on a nitrogen atom at $\delta 31.5 \mathrm{ppm}$ $\left(\mathrm{C}-3^{\prime}\right)$. In turn, the corresponding proton of this later signal was coupled to the carbonyl group at $\delta 173.2 \mathrm{ppm}$. The $\mathrm{N}$-methylalanine moiety displayed two sets of signals (ratio 3:1) in ${ }^{1} \mathrm{H}$ NMR spectrum of $\mathbf{1}$, consistent with a syn/anti rotamer equilibrium typically observed with tertiary amides [17], the major conformer being the syn one as deducted from the NOESY correlation $\mathrm{H}-2$ and $\mathrm{H}-3^{\prime}$. Indeed, this phenomenon was also observed for structurally related pachymoside A, a glycolipid isolated from the marine sponge Pachymatisma johnstonia [3].

Table 2. NMR data for the aglycone ${ }^{\text {a }}$ moieties of erylusamides A-D (1-4) in pyridine- $d_{5}$.

\begin{tabular}{|c|c|c|c|c|c|c|c|c|c|c|c|}
\hline \multicolumn{3}{|c|}{1} & \multicolumn{3}{|c|}{2} & \multicolumn{3}{|c|}{3} & \multicolumn{3}{|c|}{4} \\
\hline $\mathbf{N}^{\circ}$ & ${ }^{\delta}{ }^{13} \mathrm{C}$ & $\begin{array}{c}\delta^{1} \mathbf{H}, \mathbf{m} \\
(J, \mathbf{H z})\end{array}$ & $\mathbf{N}^{\circ}$ & $\delta^{13} \mathrm{C}$ & $\begin{array}{c}\delta^{1} \mathbf{H}, \mathbf{m} \\
(J, \mathrm{~Hz})\end{array}$ & $\mathbf{N}^{\circ}$ & $\delta^{13} \mathrm{C}$ & $\begin{array}{c}\delta^{1} \mathbf{H}, \mathbf{m} \\
(J, \mathbf{H z})\end{array}$ & $\mathbf{N}^{\circ}$ & $\delta^{13} \mathrm{C}$ & $\begin{array}{c}{ }^{\delta}{ }^{1} \mathrm{H}, \mathrm{m} \\
(J, \mathrm{~Hz})\end{array}$ \\
\hline 1 & 173.1 & - & & 173.1 & - & & 173.1 & - & & 173.1 & - \\
\hline 2 & 33.8 & $2.43, \mathrm{~m}$ & 2 & 33.8 & $2.43, \mathrm{~m}$ & 2 & 33.8 & $2.43, \mathrm{~m}$ & 2 & 33.8 & $2.43, \mathrm{~m}$ \\
\hline 5-12 & $29.6-29.9$ & $\begin{array}{l}\text { 1.18-1.33 } \\
\text { Overlap. }\end{array}$ & $5-12$ & $29.6-29.9$ & $\begin{array}{l}\text { 1.18-1.33 } \\
\text { Overlap. }\end{array}$ & $5-12$ & $29.7-29.9$ & $\begin{array}{l}\text { 1.18-1.32 } \\
\text { Overlap. }\end{array}$ & 5-12 & $29.6-29.9$ & $\begin{array}{l}\text { 1.19-1.33 } \\
\text { Overlap. }\end{array}$ \\
\hline 13 & 29.6 & $1.28, \mathrm{~m}$ & 13 & 29.6 & $1.28, \mathrm{~m}$ & 13 & 29.6 & $1.28, \mathrm{~m}$ & 13 & 29.6 & $1.28, \mathrm{~m}$ \\
\hline 14 & 24.2 & $1.64, \mathrm{~m}$ & 14 & 24.2 & $1.64, \mathrm{~m}$ & 14 & 24.2 & $1.64, \mathrm{~m}$ & 14 & 24.2 & $1.65, \mathrm{~m}$ \\
\hline 18 & 24.2 & $1.64, \mathrm{~m}$ & 18 & 24.2 & $1.64, \mathrm{~m}$ & 18 & 24.2 & $1.64, \mathrm{~m}$ & 18 & 24.2 & $1.65, \mathrm{~m}$ \\
\hline $19-23$ & $29.6-29.9$ & $\begin{array}{l}1.19-132 \\
\text { Overlap }\end{array}$ & $19-24$ & $29.6-29.9$ & $\begin{array}{l}1.18-1.33 \\
\text { Overlap }\end{array}$ & $19-24$ & $29.7-29.9$ & $\begin{array}{l}\text { 1.18-1.32 } \\
\text { Overlap }\end{array}$ & $19-25$ & $29.7-29.9$ & $\begin{array}{l}\text { 1.19-1.33 } \\
\text { Overlap }\end{array}$ \\
\hline 24 & 29.7 & $1.83, \mathrm{~m}$ & 25 & 29.7 & $1.82, \mathrm{~m}$ & 25 & 29.7 & $1.81, \mathrm{~m}$ & 26 & 29.7 & $1.83, \mathrm{~m}$ \\
\hline 25 & 74.9 & $5.53, \mathrm{~m}$ & 26 & 74.9 & $5.53, \mathrm{~m}$ & 26 & 74.9 & $5.54, \mathrm{~m}$ & 27 & 74.9 & $5.54, \mathrm{~m}$ \\
\hline $\mathrm{AcO}$ & $169.7^{*}$ & & $\mathrm{AcO}$ & $169.7^{*}$ & & $\mathrm{AcO}$ & $169.7^{*}$ & & $\mathrm{AcO}$ & $169.7^{*}$ & \\
\hline 26 & 80.7 & $4.03, \mathrm{~m}$ & 27 & 80.8 & $4.03, \mathrm{~m}$ & 27 & 80.7 & $4.03, \mathrm{~m}$ & 28 & 80.8 & $4.05, \mathrm{~m}$ \\
\hline 27 & 30.9 & $1.79, \mathrm{~m}$ & 28 & 30.9 & $1.79, \mathrm{~m}$ & 28 & 39.1 & $1.16, \mathrm{~m}$ & 29 & 30.9 & $1.80, \mathrm{~m}$ \\
\hline 28 & 32.0 & $1.23, \mathrm{~m}$ & 29 & 32.0 & $1.23, \mathrm{~m}$ & 29 & 28.2 & $1.51, \mathrm{~m}$ & 30 & 32.0 & $1.25, \mathrm{~m}$ \\
\hline $3^{\prime}$ & $\begin{array}{l}31.5 \\
28.9\end{array}$ & $\begin{array}{l}3.06, \mathrm{~s} \\
3.14, \mathrm{~s}\end{array}$ & $3^{\prime}$ & $\begin{array}{l}31.5 \\
28.9\end{array}$ & $\begin{array}{l}3.06, \mathrm{~s} \\
3.13, \mathrm{~s}\end{array}$ & $3^{\prime}$ & $\begin{array}{l}31.5 \\
28.9\end{array}$ & $\begin{array}{l}3.06, \mathrm{~s} \\
3.14, \mathrm{~s}\end{array}$ & $3^{\prime}$ & $\begin{array}{l}31.5 \\
28.9\end{array}$ & $\begin{array}{l}3.07, \mathrm{~s} \\
3.15, \mathrm{~s}\end{array}$ \\
\hline $4^{\prime}$ & $\begin{array}{l}15.0 \\
16.0\end{array}$ & $\begin{array}{l}1.54, \mathrm{~d}(7.3) \\
1.60, \mathrm{~d}(7.2)\end{array}$ & $4^{\prime}$ & $\begin{array}{l}15.0 \\
16.0\end{array}$ & $\begin{array}{l}1.55, \mathrm{~d}(7.3) \\
1.69, \mathrm{~d}(7.1)\end{array}$ & $4^{\prime}$ & $\begin{array}{l}15.0 \\
16.0\end{array}$ & $\begin{array}{l}1.55, \mathrm{~d}(7.3) \\
1.60, \mathrm{~d}(7.3)\end{array}$ & $4^{\prime}$ & $\begin{array}{l}15.0 \\
16.0\end{array}$ & $\begin{array}{l}1.54, \mathrm{~d}(7.4) \\
1.61, \mathrm{~d}(7.2)\end{array}$ \\
\hline
\end{tabular}


Table 3. NMR data for the carbohydrate moieties of erylusamides A-D (1-4) in pyridine- $d_{5}$.

\begin{tabular}{|c|c|c|c|c|c|c|c|c|}
\hline \multirow{2}{*}{ Position } & \multicolumn{2}{|r|}{1} & \multicolumn{2}{|r|}{2} & \multicolumn{2}{|r|}{3} & \multicolumn{2}{|r|}{4} \\
\hline & $\delta^{13} \mathrm{C}$ & $\delta^{1} \mathrm{H}, \mathrm{m}(J, \mathrm{~Hz})$ & $\delta^{13} \mathrm{C}$ & $\delta^{1} \mathrm{H}, \mathrm{m}(\mathrm{J}, \mathrm{Hz})$ & $\delta^{13} \mathrm{C}$ & $\delta^{1} \mathrm{H}, \mathrm{m}(J, \mathrm{~Hz})$ & $\delta^{13} \mathrm{C}$ & $\delta^{1} \mathrm{H}, \mathrm{m}(J, \mathrm{~Hz})$ \\
\hline \multicolumn{9}{|c|}{ Gal } \\
\hline 1 & 104.4 & $5.16, \mathrm{~d}(7.5)$ & 104.4 & $5.16, \mathrm{~d}(7.7)$ & 104.4 & $5.15, \mathrm{~d}(7.6)$ & 104.4 & $5.16, \mathrm{~d}(7.7)$ \\
\hline 2 & 70.7 & $4.54, \mathrm{~m}$ & 70.7 & $4.53, \mathrm{~m}$ & 70.7 & $4.53, \mathrm{~m}$ & 70.72 & $4.53, \mathrm{~m}$ \\
\hline 3 & 84.4 & $4.24, \mathrm{~m}$ & 84.3 & $4.25, \mathrm{~m}$ & 84.3 & $4.25, \mathrm{~m}$ & 84.32 & $4.24, \mathrm{~m}$ \\
\hline 4 & 69.0 & 4.70, brs & 68.9 & 4.71 , brs & 68.7 & 4.71 , brs & 68.91 & 4.72 , brs \\
\hline 5 & 77.3 & $4.21, \mathrm{~m}$ & 77.4 & $4.20, \mathrm{~m}$ & 77.3 & $4.21, \mathrm{~m}$ & 77.27 & $4.20, \mathrm{~m}$ \\
\hline 6 & 61.6 & $\begin{array}{c}4.38, \mathrm{dd} \\
(5.1 ; 10.6) \\
4.44, \mathrm{dd} \\
(6.8 ; 10.6)\end{array}$ & 61.6 & $\begin{array}{c}4.38, \mathrm{dd} \\
(5.2 ; 10.6) \\
4.43, \mathrm{dd} \\
(6.9 ; 10.6)\end{array}$ & 61.6 & $\begin{array}{c}4.38, \mathrm{dd} \\
(4.9 ; 10.9) \\
4.44, \mathrm{dd} \\
(6.7 ; 10.9)\end{array}$ & 61.62 & $\begin{array}{c}4.38, \mathrm{dd} \\
(5.2 ; 10.6) \\
4.44, \mathrm{dd} \\
(6.9 ; 10.6)\end{array}$ \\
\hline \multicolumn{9}{|c|}{ Xyl } \\
\hline 1 & 103.2 & $4.90, \mathrm{~d}(7.3)$ & 103.2 & $4.89, \mathrm{~d}(7.3)$ & 103.2 & $4.90, \mathrm{~d}(7.6)$ & 103.2 & $4.90, \mathrm{~d}(7.4)$ \\
\hline 2 & 78.3 & $4.22, \mathrm{~m}$ & 78.2 & $4.22, \mathrm{~m}$ & 78.3 & $4.21, \mathrm{~m}$ & 78.3 & $4.21, \mathrm{~m}$ \\
\hline 3 & 88.2 & $4.25, \mathrm{~m}$ & 88.1 & $4.24, \mathrm{~m}$ & 88.0 & $4.24, \mathrm{~m}$ & 88.0 & $4.26, \mathrm{~m}$ \\
\hline 4 & 69.0 & $4.00, \mathrm{~m}$ & 68.9 & $3.99, \mathrm{~m}$ & 69.0 & $3.99, \mathrm{~m}$ & 69.0 & $4.00, \mathrm{~m}$ \\
\hline 5 & 65.9 & $\begin{array}{c}3.51, \mathrm{t}(10.7) \\
4.14, \mathrm{~m}\end{array}$ & 65.9 & $\begin{array}{c}3.50, \mathrm{t}(9.8) \\
4.14, \mathrm{~m}\end{array}$ & 65.9 & $\begin{array}{c}3.51, \mathrm{t}(10.3) \\
4.14, \mathrm{~m}\end{array}$ & 65.9 & $\begin{array}{c}3.51, \mathrm{t}(10.7) \\
4.13, \mathrm{~m}\end{array}$ \\
\hline \multicolumn{9}{|c|}{ Glc1 } \\
\hline 1 & 104.6 & $4.86, \mathrm{~d}(7.9)$ & 104.6 & $4.87, \mathrm{~d}(7.8)$ & 104.6 & $4.88, \mathrm{~d}(8.0)$ & 104.6 & $4.87, \mathrm{~d}(8.0)$ \\
\hline 2 & 74.9 & $3.97, \mathrm{~m}$ & 74.6 & $3.96, \mathrm{~m}$ & 74.6 & $3.97, \mathrm{~m}$ & 74.6 & $3.98, \mathrm{~m}$ \\
\hline 3 & 76.6 & $4.18, \mathrm{~m}$ & 76.6 & $4.18, \mathrm{~m}$ & 76.6 & $4.18, \mathrm{~m}$ & 76.6 & $4.18, \mathrm{~m}$ \\
\hline 4 & 81.9 & $3.97, \mathrm{~m}$ & 81.8 & $3.97, \mathrm{~m}$ & 81.9 & $3.97, \mathrm{~m}$ & 81.9 & $3.97, \mathrm{~m}$ \\
\hline 5 & 73.0 & $4.09, \mathrm{~m}$ & 72.9 & $4.08, \mathrm{~m}$ & 73.0 & $4.10, \mathrm{~m}$ & 73.0 & $4.11, \mathrm{~m}$ \\
\hline 6 & 64.3 & $\begin{array}{l}4.92, \mathrm{~m} \\
5.16, \mathrm{~m}\end{array}$ & 64.3 & $\begin{array}{l}4.93, \mathrm{~m} \\
5.14, \mathrm{~m}\end{array}$ & 64.1 & $\begin{array}{l}4.93, \mathrm{~m} \\
5.16, \mathrm{~m}\end{array}$ & 64.3 & $\begin{array}{l}4.93, \mathrm{~m} \\
5.15, \mathrm{~m}\end{array}$ \\
\hline Ac (C-6) & 171.0 & - & & - & 171.0 & & 171.0 & - \\
\hline \multicolumn{9}{|c|}{ Glc2 } \\
\hline 1 & 102.8 & $5.55, \mathrm{~d}(8.0)$ & 102.8 & $5.55, \mathrm{~d}(8.2)$ & 102.8 & $5.55, \mathrm{~d}(8.5)$ & 102.8 & $5.55, \mathrm{~d}(8.1)$ \\
\hline 2 & 72.2 & $\begin{array}{l}5.48, \mathrm{dd} \\
(8.2 ; 9.5) \\
\end{array}$ & 72.2 & $\begin{array}{c}5.47, \mathrm{dd} \\
(8.4 ; 9.3) \\
\end{array}$ & 72.2 & $\begin{array}{c}5.48, \mathrm{t} \\
(9.3) \\
\end{array}$ & 72.1 & $\begin{array}{l}5.48, \mathrm{dd} \\
(8.4 ; 9.3) \\
\end{array}$ \\
\hline 3 & 73.5 & $5.78, \mathrm{t}(9.6)$ & 73.5 & $5.78, \mathrm{t}(9.6)$ & 73.5 & $5.78, \mathrm{t}(9.9)$ & 73.4 & $5.78, \mathrm{t}(9.5)$ \\
\hline 4 & 69.4 & $5.42, \mathrm{t}(9.8)$ & 69.4 & $5.42, \mathrm{t}(9.7)$ & 69.4 & $5.42, \mathrm{t}(9.7)$ & 69.4 & $5.42, \mathrm{t}(9.7)$ \\
\hline 5 & 72.1 & $4.22, \mathrm{~m}$ & 72.1 & $4.21, \mathrm{~m}$ & 72.1 & $4.22, \mathrm{~m}$ & 72.1 & $4.22, \mathrm{~m}$ \\
\hline 6 & 62.7 & $\begin{array}{c}4.32, \mathrm{dd} \\
(2.3 ; 12.1) \\
4.51, \mathrm{dd} \\
(5.4 ; 12.1)\end{array}$ & 62.7 & $\begin{array}{c}4.32, \mathrm{dd} \\
(2.1 ; 11.8) \\
4.50, \mathrm{dd}, \\
(5.3 ; 12.0)\end{array}$ & 62.6 & $\begin{array}{c}4.31, \mathrm{dd} \\
(\sim 2 ; 11.8) \\
4.52, \mathrm{dd} \\
(4.8 ; 11.8)\end{array}$ & 62.7 & $\begin{array}{c}4.31, \mathrm{dd} \\
(2.3 ; 12.1) \\
4.51, \mathrm{dd} \\
(5.4 ; 12.1)\end{array}$ \\
\hline Ac (C-2) & 170.2 & - & 170.2 & - & 170.2 & - & 170.2 & - \\
\hline Ac (C-3) & 170.1 & - & 170.1 & - & 172.2 & - & 170.2 & - \\
\hline Ac (C4) & 169.8 & - & 169.9 & - & 169.9 & - & 169.9 & - \\
\hline Ac (C-6) & 170.4 & - & 170.5 & - & 170.5 & - & 170.5 & - \\
\hline \multicolumn{9}{|c|}{ Glc3 } \\
\hline 1 & 99.6 & $6.37, \mathrm{~d}(7.9)$ & 99.6 & $6.35, \mathrm{~d}(8.0)$ & 99.6 & $6.36, d(7.6)$ & 99.6 & $6.36, \mathrm{~d}(7.9)$ \\
\hline 2 & 72.3 & $5.62, \mathrm{~m}$ & 72.2 & $5.61, \mathrm{t}(10)$ & 72.2 & $5.62, \mathrm{~m}$ & 72.2 & $5.62, \mathrm{~m}$ \\
\hline 3 & 73.7 & $5.90, \mathrm{t}(9.4)$ & 73.7 & $5.89, \mathrm{t}(9.5)$ & 73.7 & $5.9, \mathrm{t}(9.3)$ & 73.7 & $5.90, \mathrm{t}(9.5)$ \\
\hline 4 & 69.7 & $5.58, \mathrm{~m}$ & 69.7 & $5.56, \mathrm{~m}$ & 69.7 & $5.56, \mathrm{~m}$ & 69.7 & $5.56, \mathrm{~m}$ \\
\hline 5 & 72.3 & $3.93, \mathrm{~m}$ & 72.2 & $3.92, \mathrm{~m}$ & & & 72.2 & $3.92, \mathrm{~m}$ \\
\hline 6 & 62.5 & $\begin{array}{l}4.19, \mathrm{~m} \\
4.57, \mathrm{~m}\end{array}$ & 62.5 & $\begin{array}{l}4.56, \mathrm{~m} \\
4.18, \mathrm{~m}\end{array}$ & 62.4 & $\begin{array}{l}4.19, \mathrm{~m} \\
4.56, \mathrm{~m}\end{array}$ & 62.4 & $\begin{array}{l}4.18, \mathrm{~m} \\
4.57, \mathrm{~m}\end{array}$ \\
\hline $\mathrm{Ac}(\mathrm{C}-2)$ & 169.6 & - & 169.6 & - & 169.7 & - & 169.7 & - \\
\hline $\mathrm{Ac}(\mathrm{C}-3)$ & 170.5 & - & 170.5 & - & 170.5 & - & 170.5 & - \\
\hline Ac(C-4) & 169.7 & - & 169.7 & - & 169.8 & - & 169.7 & - \\
\hline Ac(C-6) & 170.2 & - & 170.4 & - & 170.4 & - & 170.4 & - \\
\hline
\end{tabular}




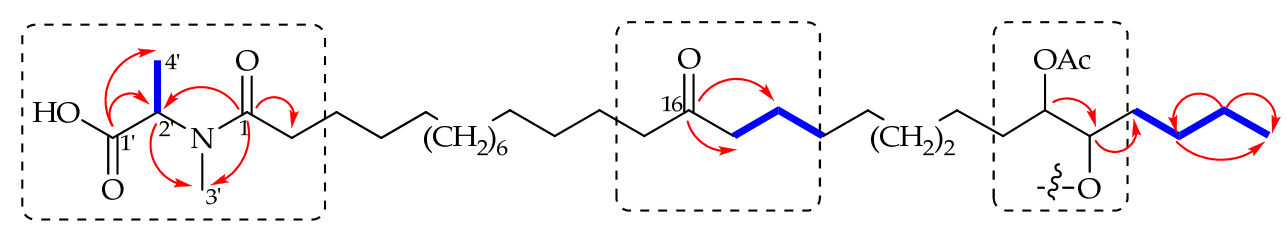

Figure 2. Key HMBC (red ashes) and HSQC-TOCSY (blue lines) correlations establishing the structure of the aglycone moiety.

The presence of two vicinal oxymethine groups constituting an isolated stereocluster was the most striking feature of the aglycone moiety. In the HSQC spectrum, the crosspeaks at $\delta 80.7 / \delta 4.03$ and $\delta 74.9 / \delta 5.53$ suggested the presence of two non-equivalent secondary $O$-substituted alcohols. An HMBC cross-peak was observed between the proton at $\delta 4.03$ and the carbon at $\delta 74.8 \mathrm{ppm}$. However, no COSY correlation was observed between the two oxymethine signals suggesting that the dihedral angle between the two protons should be around $90^{\circ}$ [18]. These data were consistent with a vicinal diol, with one hydroxyl group acylated and the other one linked to a sugar moiety $[19,20]$. Furthermore, a connection could be assigned between this diol moiety and terminal $n$-butyl, as depicted from the H2B crosspeak between C-26 $(\delta 80.7)$ and the proton at $\delta 1.79 \mathrm{ppm}(\mathrm{H}-27)$, as well as HSQC-TOCSY long range correlations $30.9 \rightarrow 32.0 \rightarrow 22.8 \rightarrow 14.7 \rightarrow 0.84$. The remaining deshielded signal at $\delta 210.5$ corresponded to an aliphatic symmetrical ketone, as deduced from the HMBC correlation with two separated $\mathrm{CH}_{2}$ signals at $\delta 2.42(4 \mathrm{H})$ and $1.64(4 \mathrm{H}) \mathrm{ppm}$. Compound 1 was methanolysed to liberate the aglycone methyl ester (compound 5, Figure 3), which was further converted in the corresponding acetonide, and their MS and NMR spectra (see Sections 3.4 and 3.7) analysed and compared with those of compound 1. Compound 5 showed a molecular adduct ion $[\mathrm{M}+\mathrm{Na}]^{+}$at $m / z 620.5$ (Figure 3) compatible with the methyl ester of the deacetylated free aglycone. Comparison of this result with the ones obtained from MS analysis of compound 1 confirmed the presence of an acetyl group on the aglycone moiety: the MS/MS data on molecular ion $[\mathrm{M}-\mathrm{H}]^{-}$at $m / z 1782.8$ of compound 1 showed a fragment ion at $m / z 624.5$, due to the loss of the oligosaccharide portion, compatible with an monoacetylated aglycone moiety. Additionally, a detailed analysis of tandem mass spectrometry (ESI ${ }^{+}$-MS/MS) data (Figure 3) obtained on the aglycone methyl ester 5, at $m / z 620.5$, suggested the location of the carbonyl function at C-16 in the aliphatic chain. In fact, product ion spectra contained diagnostic ions at $m / z 265.3\left[\mathrm{C}_{15} \mathrm{H}_{30} \mathrm{O}_{2}+\mathrm{Na}\right]^{+}$and 390.3 formally arising from $\alpha$-cleavage of the carbonyl group. Furthermore, a fragment ion at $m / z 138.1$ confirmed the presence of the $N$-methylalanine moiety.

Finally, analysis of NMR spectra of the acetonide 6 (see Section 3.7) confirmed the occurrence and relative stereochemistry of the 1,2 diol system: the two oxymethine protons at $\delta 3.72$ and 3.74 were coupled by $\mathrm{H} 2 \mathrm{BC}$ to the downfield shifted carbons at $\delta 81.4$ and 1.5 , respectively, as well as by HMBC with the oxygenated carbon signal at $\delta 107.8$, bearing, in turn, the two acetonide methyl groups at $\delta 1.50$ ). According to the carbon chemical shifts of these methyl groups of 6 , overlapping at $27.0 \mathrm{ppm}$, the relative stereochemistry of the 1,2-diol was proposed as threo. [21-23].

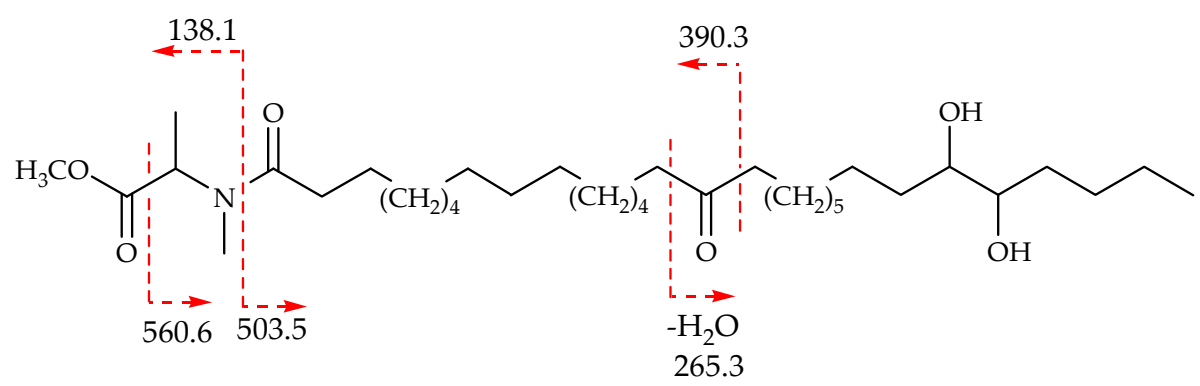

Figure 3. ESI-MS/MS analysis of the aglycone methyl ester 5 at $m / z 620.5[\mathrm{M}+\mathrm{Na}]^{+}$. 
The aglycone part as described above accounted for four out of the 18 formal unsaturations predicted by the molecular formula of $\mathbf{1}$. Thus, the remaining 14 double bond equivalents were attributable to the glucosidic portion. The analysis of the ${ }^{1} \mathrm{H},{ }^{13} \mathrm{C}$ and HSQC spectra revealed five anomeric carbons, accounting for five sugar rings. The remaining formal unsaturations were assigned to nine acetate residues, which fulfilled the observed $[\mathrm{M}-\mathrm{H}]^{-}$ion peak at $m / z 1782.8345$.

Hydrolysis of compound 1 showed that D-xylose, D-galactose and D-glucose were the only monomers present with a ration 1:1:3. The sequence of these sugar residues was determined by extensive NMR study, especially based on 2D techniques (COSY-45, HSQC, HSQC-TOCSY, H2BC, HMBC and NOESY) (Table 2).

The five anomeric carbons and their attached protons were unequivocally identified at $\delta^{13} \mathrm{C} /{ }^{1} \mathrm{H}$ : 104.6/4.86 (d, $J=7.9 \mathrm{~Hz}) ; 104.4 / 5.16(\mathrm{~d}, J=7.5 \mathrm{~Hz}) ; 103.2 / 4.90(\mathrm{~d}, J=7.3 \mathrm{~Hz}) ; 102.8 / 5.55(\mathrm{~d}, J=8.0 \mathrm{~Hz})$ and $99.6 / 6.37(\mathrm{~d}, J=7.9 \mathrm{~Hz}$ ) (Figure 4). The anomeric configurations were assigned as $\beta$ from the magnitude of the ${ }^{3} J_{1,2}$, values, all within the $7-9 \mathrm{~Hz}$ interval, typical of diaxial proton coupling [24]. Moreover, the ${ }^{13} \mathrm{C}$ NMR shifts of the anomeric carbons, approximatively $100 \mathrm{ppm}$, also indicate that the corresponding sugars are connected through $\beta$-glycosidic bonds $[25,26]$.

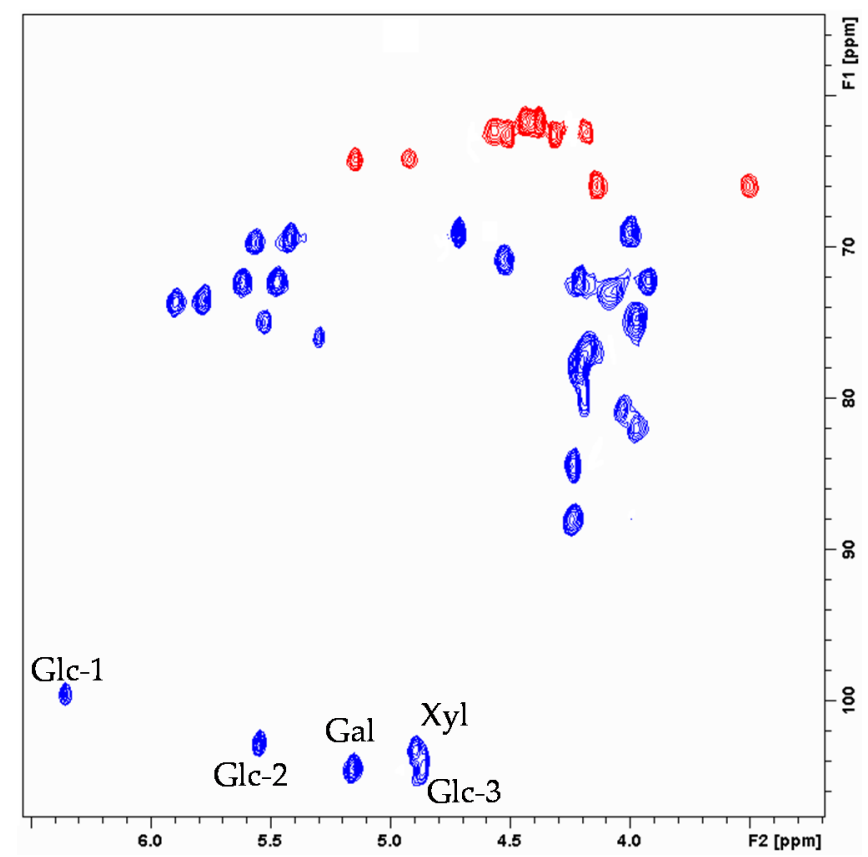

Figure 4. Expansion of HSQC spectrum of erylusamide A (1) showing the anomeric carbon, the oxymethines and oxymethylenes correlations.

Six of the oxymethines ( $\delta \mathrm{H} 5.90,5.78,5.62,5.58,5.48$ and 5.42) and three of the oxymethylenes $(\delta \mathrm{H} 4.51 / 4.32,4.57 / 4.19,5.16 / 4.92)$ had proton resonating at 1-2 ppm downfield with respect to free hydroxyl groups [19], which indicated the sites of acetylation (Figure 4). The position of acetyl groups was ascertained by HMBC correlations between the acetyl carbonyls and the corresponding oxymethine protons (Figure 5).

The long-range HMBC correlation between C-26 $(\delta 80.7 \mathrm{ppm})$ and the $\beta$-anomeric proton at $\delta 4.86$ disclosed the linkage between the aglycone portion and the first unit of the pentasaccharide chain, which was assigned to a monoacetylated glucose residue (Glc1). In fact, starting from the anomeric proton TOCSY experiments allowed to delineate the entire spin system while relative configuration was achieved by analysis of NOESY data and J couplings. Furthermore, H-6 methylene resulted deshielded thus suggesting the first acetylation site. The MS/MS fragment at $m / z 828.5$ [aglyconeGlc1 $-\mathrm{H}]^{-}$) from the ion $[\mathrm{M}-\mathrm{H}]^{-}$at $m / z 1782.8$ is compatible with a monoacetylated glucose. 


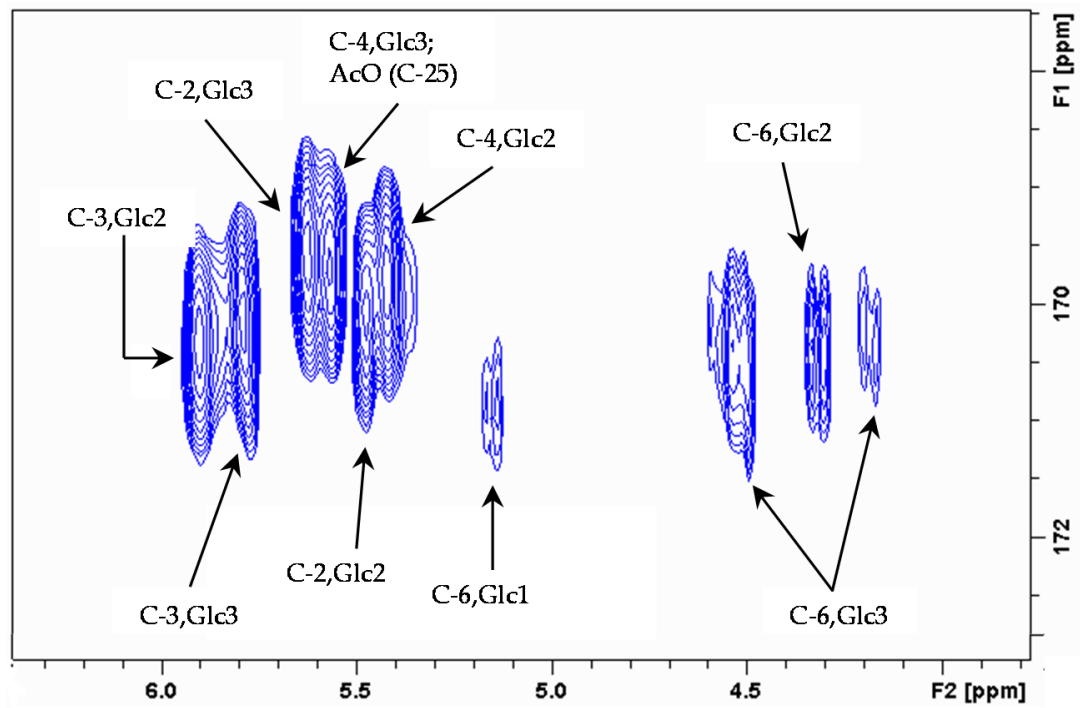

Figure 5. Expansion of HMBC spectrum showing correlations to acetate carbonyls in sugar moiety.

The HMBC cross peak between C-4 Glc1 and the anomeric proton at 4.90 identified the glycosidic bond between this glucose and the xylose residue, confirmed by the correlation between $\mathrm{C}-1 \mathrm{Xyl}$ and $\mathrm{H}-4$ Glc1. Xylose showed another glycosidic bond with another glucose residue, which was depicted from cross peaks C-2 Xyl/H-1 Glc3 and C-1 Glc3/H-2 Xyl. A third $\beta$-glycosidic bond between xylose and a galactose residue was apparent from the long range correlation C-3 Xyl/ H-1 Gal and the NOESY correlation $\mathrm{H}-3 \mathrm{Xyl} / \mathrm{H}-1 \mathrm{Gal}$. Finally, the galactose residue was connected to another glucose unit through the cross peak between C-3 Gal and H-1 Glc2 (Figure 6).

HR-ESI-MS of erylusamides B (2) and C (3) showed [M - H] ${ }^{-}$ions at $m / z 1796.8515$ and 1796.8434 respectively, consistent with the empirical formula $\mathrm{C}_{84} \mathrm{H}_{135} \mathrm{NO}_{40}$, suggesting an isomeric relationship, which was reflected in a different behaviour of the two metabolites in HPLC analysis. A careful comparison of NMR spectra indicated structures with aglycones closely related to erylusamide A, which differed for an extra methylene, also confirmed by the peak at $m / z 638.5$ [aglycone $-\mathrm{H}]^{-}$ $\left(\mathrm{C}_{37} \mathrm{H}_{68} \mathrm{O}_{7} \mathrm{~N}\right)$ in both $\mathrm{ESI}^{-}-\mathrm{MS} / \mathrm{MS}$ analyses.

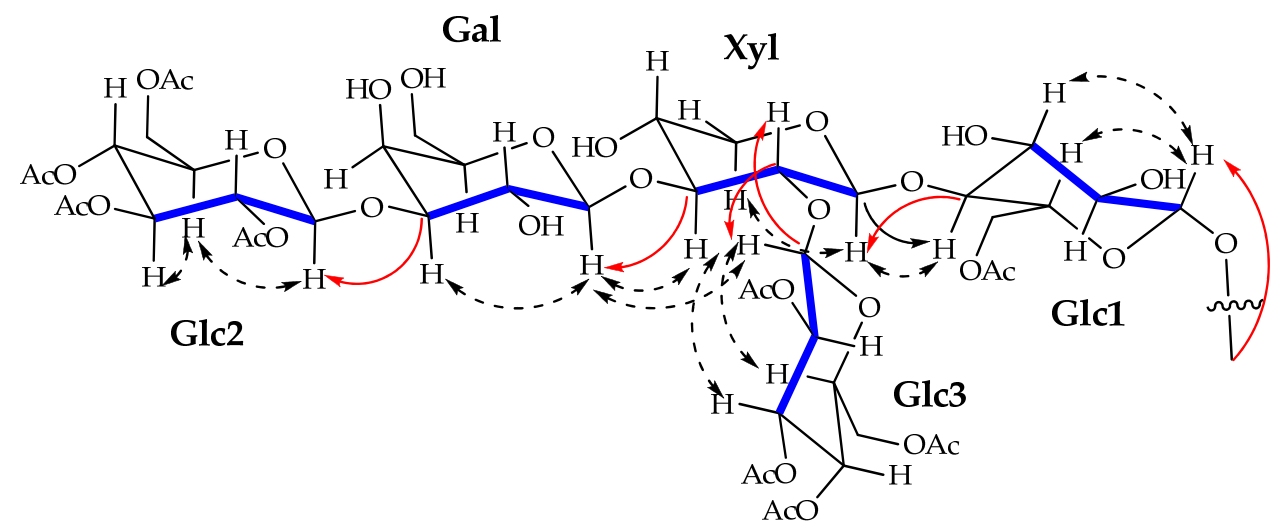

Figure 6. Key HMBC (red ashes), NOESY (dashed ashes) and HSQC-TOCSY (blue lines) correlations establishing the structure of the pentasaccharide moiety.

${ }^{1} \mathrm{H}$ and ${ }^{13} \mathrm{C}$ NMR spectra of compound $\mathbf{2}$ were almost superimposable with those of $\mathbf{1}$, suggesting that the additional methylene should be positioned within the long hydrocarbon chain. Furthermore, NMR data showed that the only difference between the isomeric compounds $\mathbf{2}$ and $\mathbf{3}$ was at one chain end of the aglycone moiety, where an isobutyl group in $\mathbf{3}$ replaced the terminal $n$-butyl residue of 2 . 
In fact, the ${ }^{1} \mathrm{H}$ NMR spectrum of 3 showed the presence of a doublet at $\delta 0.85 \mathrm{ppm}(6 \mathrm{H}, J=6.0 \mathrm{~Hz})$ and a multiplet signal at $\delta 1.51$ assigned, respectively, to the methyl and methine protons of the isobutyl moiety. The signal at $\delta 1.16$ was attributed to the remaining methylene group. The two equivalent methyl carbons of the isobutyl moiety were observed at $\delta 22.8 \mathrm{ppm}$, while the methine carbon and the methylene appeared, respectively, at $\delta 28.2$ and $\delta 39.1 \mathrm{ppm}$.

Erylusamide D (4) had a molecular formula of $\mathrm{C}_{85} \mathrm{H}_{136} \mathrm{O}_{40} \mathrm{~N}$ as revealed by HR-MS-ESI [M $\left.-\mathrm{H}\right]^{-}$ molecular ion peak at 1810.8644. NMR spectra of 4 and $\mathbf{1}$ were almost superimposable, the only difference being, as for compound 2, the length of the hydrocarbon chain that has two extra methylene groups, confirmed by the presence, in the $\mathrm{ESI}^{-}$-MS/MS spectrum, of the fragment at $\mathrm{m} / \mathrm{z} 652.5$ [aglycone $-\mathrm{H}]^{-}\left(\mathrm{C}_{38} \mathrm{H}_{70} \mathrm{O}_{7} \mathrm{~N}\right)$.

In conclusion, the bioassay guided fractionation of the dichloromethane extract of the marine sponge Erylus cf. deficiens afforded a glycolipid fraction showing IDO inhibitory activity, from which were isolated four new polyketide glycosides structurally related to erylusamines reported in congener sponges [6-8]. The identification of the glycolipid content of sponges is important, not only due to the bioactivity that they usually display, but also because they have become useful markers in the taxonomic classification.

\section{Materials and Methods}

\subsection{General Experimental Procedures}

NMR spectra were acquired on a Bruker DRX-600 apparatus (Bruker BioSpin GmbH, Rheinstetten, Germany) operating at 600 for ${ }^{1} \mathrm{H}$ and $150 \mathrm{MHz}$ for ${ }^{13} \mathrm{C}$ ). Chemical shifts were expressed as $\delta$ values and reported to the residual solvent signals (pyridine- $d_{5}, \delta_{\mathrm{H}}=8.73,7.58$ and $7.21 ; \delta_{\mathrm{C}}=149.9,135.5$ and 123.5); coupling constants were reported in units of Hertz $(\mathrm{Hz})$. HR-ESI-MS analysis was run on a Q-Exactive mass spectrometer (Thermo Fisher Scientific, Rockford, IL, USA). ESI-MS/MS spectra were achieved on a Q-Tof micro mass spectrometer (Waters, Milford, MA, USA). GC-MS analysis were performed on a Shimadzu GCMS-QP 2010Plus (Kyoto, Japan) using a Teknokroma TRB-1 column $(30 \mathrm{~m} \times 0.25 \mu \mathrm{m})$ (Barcelone, Spain).

IR spectra were obtained using a Mattson Satellite FT-IR (Waltham, MA, USA) and only the diagnostic absorption bands are reported, in $\mathrm{cm}^{-1}$. Flash column chromatography was performed on reversed-phase silica gel LiChroprep ${ }^{\circledR}$ RP-18 40-63 $\mu \mathrm{m}$ (Merck Ref. 113900, Darmstadt, Germany). Thin layer chromatography was performed on silica gel $60 \mathrm{~F}_{254}$ aluminum sheets (Merck Ref. 5554) and visualized with UV light $(254 \mathrm{~nm})$ and vanillin/sulfuric reagent $(0.5 \mathrm{~g}$ vanillin in sulfuric $/ \mathrm{MeOH}$ $4: 1 \mathrm{v} / \mathrm{v}$ ) followed by heating up to $120^{\circ} \mathrm{C}$.

HPLC separations were performed on an Ultimate 3000 Dionex liquid chromatograph (Germering, Germany) equipped with a Phenomenex Luna $2.6 \mu$ phenyl-hexyl column $100 \AA(150 \mathrm{~mm} \times 4.60 \mathrm{~mm})$ (Torrance, LA, USA).

All solvents and reagents were obtained from commercial suppliers and were used without further purification.

\subsection{Biological Material}

A specimen of Erylus cf. deficiens Topsent, 1927 (Demospongiae, Tetractinellida, Geodiidae) was collected by scuba diving on the Gorringe Bank, a seamount located $150 \mathrm{~km}$ off the southwest coast of Portugal, at a depth between 40 and $50 \mathrm{~m}$, and kept at $-20{ }^{\circ} \mathrm{C}$ until processed. Identification was performed through analyses of the skeletal characters (spicules) under optical microscopy. A voucher sample was preserved in 90\% ethanol and deposited in the Biology Department's zoological collection of the University of the Azores, Ponta Delgada, Portugal (collection DBUA.Por). 


\subsection{Extraction and Isolation Procedures}

The lyophilized specimens $(63 \mathrm{~g})$ were triturated in a grinder and extracted with methanol at room temperature for $24 \mathrm{~h}$, yielding $7.2 \mathrm{~g}$ of crude extract after solvent evaporation under vacuum. This methanol extract was subsequently re-extracted with dichloromethane for $24 \mathrm{~h}$, at room temperature, affording $1.8 \mathrm{~g}$ of extract. An aliquot of the dichlorometane extract $(0.958 \mathrm{~g})$ was coarse fractionated by RP-C18 flash chromatography with an eluent gradient of decreasing polarity from methanol to dichloromethane/methanol 9:1, in a total of 11 fractions. The more active fraction in the bioassay (fraction 2, $150 \mathrm{mg}$, eluent: methanol) was fractionated by HPLC using a column Phenomenex Luna $2.6 \mu$ phenyl-hexyl $100 \AA$ ( $150 \mathrm{~mm} \times 4.60 \mathrm{~mm}$ ) and a gradient of $\mathrm{MeOH} / 0.1 \% \mathrm{TFA}$ in $\mathrm{H}_{2} \mathrm{O}$ (flow $0.75 \mathrm{~mL} \cdot \mathrm{min}^{-1}$ from 80:20 to $100 \% \mathrm{MeOH}$ ). Erylusamides A-D (compounds 1-4) were obtained by injection of more than two hundred $10 \mu \mathrm{L}$ samples and pooling homologues fractions. Erylusamide A: (RT: $27.71 \mathrm{~min}, 27.7 \mathrm{mg}$ ), Erylusamide B: (RT: $29.10 \mathrm{~min} ; 23.0 \mathrm{mg}$ ), Erylusamide C: (RT: $30.74 \mathrm{~min}$; $17.9 \mathrm{mg}$ ) and Erylusamide D: (RT: $33.41 \mathrm{~min} ; 8.7 \mathrm{mg}$ ).

Erylusamide A (1): Colorless oil; ${ }^{1} \mathrm{H}$ and ${ }^{13} \mathrm{C}$ NMR data, see Tables 2 and 3; HR-ESIMS $\mathrm{m} / z$

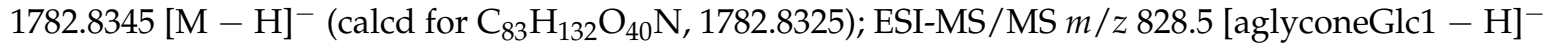
$\left(\mathrm{C}_{44} \mathrm{H}_{78} \mathrm{O}_{13} \mathrm{~N}\right), 624.5$ [aglycone $\left.-\mathrm{H}\right]^{-}\left(\mathrm{C}_{36} \mathrm{H}_{66} \mathrm{O}_{7} \mathrm{~N}\right)$.

Erylusamide B (2): Colorless oil; ${ }^{1} \mathrm{H}$ and ${ }^{13} \mathrm{C}$ NMR data, see Tables 2 and 3; HR-ESIMS $\mathrm{m} / \mathrm{z}$ $1796.8515[\mathrm{M}-\mathrm{H}]^{-}$(calcd for $\mathrm{C}_{84} \mathrm{H}_{134} \mathrm{O}_{40} \mathrm{~N}, 1796.8482$ ). ESI-MS/MS $m / z$ 842.6 [aglyconeGlc1 $\left.-\mathrm{H}\right]^{-}$ $\left(\mathrm{C}_{45} \mathrm{H}_{80} \mathrm{O}_{13} \mathrm{~N}\right), 638.5$ [aglycone $\left.-\mathrm{H}\right]^{-}\left(\mathrm{C}_{37} \mathrm{H}_{68} \mathrm{O}_{7} \mathrm{~N}\right)$.

Erylusamide C (3): Colorless oil; ${ }^{1} \mathrm{H}$ and ${ }^{13} \mathrm{C}$ NMR data, see Tables 2 and 3; HR-ESIMS $\mathrm{m} / \mathrm{z}$ $1796.8434[\mathrm{M}-\mathrm{H}]^{-}$(calcd for $\mathrm{C}_{84} \mathrm{H}_{134} \mathrm{O}_{40} \mathrm{~N}, 1796.8482$ ). ESI-MS/MS $m / z$ 842.6 [aglyconeGlc1 - $\left.\mathrm{H}\right]^{-}$ $\left(\mathrm{C}_{45} \mathrm{H}_{80} \mathrm{O}_{13} \mathrm{~N}\right), 638.5$ [aglycone $\left.-\mathrm{H}\right]^{-}\left(\mathrm{C}_{37} \mathrm{H}_{68} \mathrm{O}_{7} \mathrm{~N}\right)$.

Erylusamide D (4): Colorless oil; ${ }^{1} \mathrm{H}$ and ${ }^{13} \mathrm{C}$ NMR data, see Tables 2 and 3; HR-ESIMS $\mathrm{m} / \mathrm{z}$ 1810.8644 [M - H] ${ }^{-}$(calcd for $\mathrm{C}_{85} \mathrm{H}_{136} \mathrm{O}_{40} \mathrm{~N}, 1810.8638$ ). ESI-MS/MS $m / z$ 856.6 [aglyconeGlc1 - $\left.\mathrm{H}\right]^{-}$ $\left(\mathrm{C}_{46} \mathrm{H}_{82} \mathrm{O}_{13} \mathrm{~N}\right), 652.5$ [aglycone $\left.-\mathrm{H}\right]^{-}\left(\mathrm{C}_{38} \mathrm{H}_{70} \mathrm{O}_{7} \mathrm{~N}\right)$.

\subsection{Methanolysis of Crude Fraction of Glycolipids}

A portion of the crude fraction of glycolipids $(12.9 \mathrm{mg})$ was dissolved in $1.5 \mathrm{~mL}$ of $2 \mathrm{M} \mathrm{HCl}$ in $\mathrm{MeOH}$. The reaction mixture was stirred at $80^{\circ} \mathrm{C}$ with refluxing for $4.5 \mathrm{~h}$ and, after cooling, neutralized with $5 \%$ ammonium hydroxide aqueous solution and finally evaporated to dryness under vacuum. The residue was partitioned between $\mathrm{H}_{2} \mathrm{O}$ and dichloromethane $(2 \mathrm{~mL} \times 3)$. Both phases were evaporated. The aglycone went into the organic phase and the methyl glycosides into the aqueous one.

Aglycone methyl ester (compound 5, major / ${ }^{*}$ minor rotamer):

${ }^{1} \mathrm{H}$ NMR (pyridine- $\left.d_{5}, 600 \mathrm{MHz}\right): \delta 5.38 / 4.93^{*}\left(1 \mathrm{H}, \mathrm{q}, J=7.3 \mathrm{~Hz}, \mathrm{H}-2^{\prime}\right) ; 3.96(1 \mathrm{H}, \mathrm{m}, \mathrm{H}-26) ; 3.97(1 \mathrm{H}$, $\mathrm{m}, \mathrm{H}-25) ; 3.63 / 3.67^{*}\left(3 \mathrm{H}, \mathrm{s}, \mathrm{CH}_{3} \mathrm{O}\right) ; 2.94 / 2.97^{*}\left(3 \mathrm{H}, \mathrm{s}, \mathrm{H}-3^{\prime}\right) ; 2.40(4 \mathrm{H}, \mathrm{m}, \mathrm{H}-15 / \mathrm{H}-17) ; 2.38(2 \mathrm{H}, \mathrm{m}$, H-2); 1.88 (2H, m, H-23); 1.87 (2H, m, H-27); 1.77 (2H, m, H-3);1.60 (4H, m, H-14/H-18); 1.62 (2H, m, H-28); 1.41/1.46* (3H, d, J = 7.3Hz, H-4'); 1.32 (2H, m, H-29); 1.36 (2H, m, H-4); 1.28 (2H, m, H-13); 1.26 $(24 \mathrm{H}, \mathrm{m}) ; 0.85(3 \mathrm{H}, \mathrm{t}, J=7.1 \mathrm{~Hz}, \mathrm{H}-30) .{ }^{13} \mathrm{C}$ NMR (pyridine- $\left.d_{5}, 150 \mathrm{MHz}\right): \delta 210.5(\mathrm{C}, \mathrm{C}-16) ; 173.1 / 172.9^{*}$ (C, C-1); 172.8/172.3* (C, C-1'); $75.2(\mathrm{CH}, \mathrm{C}-26) ; 75.0(\mathrm{CH}, \mathrm{C}-25) ; 53.2 / 55.6^{*}\left(\mathrm{CH}, \mathrm{C}-2^{\prime}\right) ; 51.3 / 52.2^{*}\left(\mathrm{CH}_{3}\right.$, $\left.\mathrm{CH}_{3} \mathrm{O}\right) ; 43.0\left(\mathrm{CH}_{2}, \mathrm{C}-15 / \mathrm{C}-17\right) ; 34.0\left(\mathrm{CH}_{2}, \mathrm{C}-2\right) ; 33.8\left(\mathrm{CH}_{2}, \mathrm{C}-24 / \mathrm{C}-27\right) ; 32.6\left(\mathrm{CH}_{2}, \mathrm{C}-28\right) ; 32.1 / 29.0^{*}$ $\left(\mathrm{CH}_{3}, \mathrm{C}-3^{\prime}\right) ; 29.6\left(\mathrm{CH}_{2}, \mathrm{C}-4 / \mathrm{C}-13\right) ; 27.1\left(\mathrm{CH}_{2}, \mathrm{C}-23\right) ; 25.4\left(\mathrm{CH}_{2}, \mathrm{C}-3\right) ; 24.3\left(\mathrm{CH}_{2}, \mathrm{C}-14 / \mathrm{C}-18\right) ; 23.1$ $\left(\mathrm{CH}_{2}, \mathrm{C}-29\right) ; 15.0 / 15.9^{*}\left(\mathrm{CH}_{3}, \mathrm{C}-4^{\prime}\right) ; 14.6\left(\mathrm{CH}_{3}, \mathrm{C}-30\right)$. HR-ESIMS $m / z 620.4856[\mathrm{M}+\mathrm{Na}]^{+}$(calcd. for $\left.\mathrm{C}_{35} \mathrm{H}_{67} \mathrm{O}_{6} \mathrm{NNa}, 620.4866\right)$. ESI-MS/MS $m / z 620.5[\mathrm{M}+\mathrm{Na}]^{+}, 560.6,503.5,390.3,265.3,138.1$.

\subsection{Derivatization of Glycosides}

The methyl glycosides were dissolved in $0.5 \mathrm{~mL}$ of pyridine and $36 \mu \mathrm{L}$ of trimethylsilyl chloride (TMSCl) and $106 \mu \mathrm{L}$ of hexamethyldisiloxane (HMDS) were added to the mixture. The reaction mixture 
was stirred at $60^{\circ} \mathrm{C}$ for $2 \mathrm{~h}$ and evaporated to dryness. The residue was partitioned between $\mathrm{H}_{2} \mathrm{O}$ and dichloromethane $(3 \times 1 \mathrm{~mL})$. The TMS-glycosides went into the organic phase and evaporated to dryness.

\subsection{Preparation of Monosaccharide Standards}

Commercial D-glucose, D-galactose and D-xylose were dissolved in $2 \mathrm{M} \mathrm{HCl}$ in $\mathrm{MeOH}$ and stirred with refluxing at $80^{\circ} \mathrm{C}$ for $2 \mathrm{~h}$. Thereafter, methanol and $\mathrm{HCI}$ were removed under a nitrogen stream without prior neutralization. An excess of TMSCl and HMDS were added to the dried material. The solutions were then heated at $60^{\circ} \mathrm{C}$ for $2 \mathrm{~h}$. The derivatized samples were evaporated under vacuum and used as standards for GC analysis

\subsection{Synthesis of the Acetonide of Compound 5}

Compound $5(0.77 \mathrm{mg}, 1.2 \mu \mathrm{mol})$ was dissolved in dimethoxypropane $(500 \mu \mathrm{L})$ with a catalytic amount of pyridinium $p$-toluenesulfonate (PPTS). The reaction mixture was heated at $60{ }^{\circ} \mathrm{C}$ for $5 \mathrm{~h}$, then allowed to cool at room temperature and partitioned between water and $\mathrm{Et}_{2} \mathrm{O}(4 \times 5 \mathrm{~mL})$. The organic phase was evaporated to dryness under nitrogen stream affording compound 6 ( $0.8 \mathrm{mg}$, $1.2 \mu \mathrm{mol})$.

Acetonide of compound 5:

${ }^{1} \mathrm{H}$ NMR (pyridine- $\left.d_{5}, 600 \mathrm{MHz}\right): \delta 5.37\left(1 \mathrm{H}, \mathrm{q}, J=7.3 \mathrm{~Hz}, \mathrm{H}-2^{\prime}\right) ; 3.74\left(1 \mathrm{H}, \mathrm{m}, \mathrm{H}-26^{*}\right) ; 3.72(1 \mathrm{H}, \mathrm{m}$, $\left.\mathrm{H}-25^{*}\right) ; 3.62\left(3 \mathrm{H}, \mathrm{s}, \mathrm{OCH}_{3}\right) ; 2.94\left(3 \mathrm{H}, \mathrm{s}, \mathrm{H}-3^{\prime}\right) ; 2.43(4 \mathrm{H}, \mathrm{m}, \mathrm{H}-15 / \mathrm{H}-17) ; 2.38(2 \mathrm{H}, \mathrm{m}, \mathrm{H}-2) ; 1.65(4 \mathrm{H}$, $\mathrm{m}, \mathrm{H}-14, / \mathrm{H}-18) ; 1.51\left(6 \mathrm{H}\right.$, s, acetonide $\alpha$ and $\left.\beta \mathrm{CH}_{3}\right) ; 1.41\left(3 \mathrm{H}, \mathrm{d}, J=7.3 \mathrm{~Hz}, \mathrm{H}-4^{\prime}\right) ; 1.36(2 \mathrm{H}, \mathrm{m}, \mathrm{H}-4)$; $1.30(2 \mathrm{H}, \mathrm{m}, \mathrm{H}-29) ; 1.28$ (2H, m, H-13); $0.88(3 \mathrm{H}, \mathrm{t}, J=7.3 \mathrm{~Hz}, \mathrm{H}-30) .{ }^{13} \mathrm{C}$ NMR (pyridine- $d_{5}, 150 \mathrm{MHz}$ ): $\delta 210.6$ (C, C-16); (173.2 (C, C-1); $172.7\left(\mathrm{C}, \mathrm{C}-1^{\prime}\right) ; 107.8$ (C, acetonide OCO); $81.5\left(\mathrm{CH}, \mathrm{C}-25^{*}\right) ; 81.4(\mathrm{CH}$, $\left.\mathrm{C}-26^{*}\right) ; 53.0\left(\mathrm{CH}, \mathrm{C}-2^{\prime}\right) ; 51.9\left(\mathrm{OCH}_{3}\right) ; 42.7\left(\mathrm{CH}_{2}, \mathrm{C}-15 / \mathrm{C}-17\right) ; 33.3\left(\mathrm{CH}_{2}, \mathrm{C}-27\right) ; 31.9\left(\mathrm{CH}_{3}, \mathrm{C}-1^{\prime}\right) ; 29.6$ $\left(\mathrm{CH}_{2}, \mathrm{C}-4\right) ; 29.5\left(\mathrm{CH}_{2}, \mathrm{C}-13\right) ; 28.8\left(\mathrm{CH}_{2}, \mathrm{C}-28\right) ; 27.7$ (acetonide $\left.\mathrm{CH}_{3}\right) ; 25.4\left(\mathrm{CH}_{2}, \mathrm{C}-3\right) ; 24.2\left(\mathrm{CH}_{2}, \mathrm{C}-14\right.$ / $\mathrm{C}-18) ; 23.0\left(\mathrm{CH}_{2}, \mathrm{C}-29\right) ; 14.6\left(\mathrm{CH}_{3}, \mathrm{C}^{\prime}\right) 14.2\left(\mathrm{CH}_{3}, \mathrm{C}-30\right)$.

\subsection{Bioassay Description (GPSD ${ }^{2}$ Screening Application) [15]}

Modified yeast cells from overnight growth are re-inoculated at OD 0.1 in selective medium to induce specific toxicity conditions and are dispensed automatically by a JANUS ${ }^{\circledR}$ Automated Workstation (Perkin Elmer, Waltham, MA, USA) into a 96-well plate at a final volume of $200 \mu \mathrm{L}$.

In addition, $4 \mu \mathrm{L}$ of organic and aqueous extracts (resuspended in dimethyl sulfoxide at a final concentration of $25 \mathrm{mg}$ dry extract $/ \mathrm{mL}$ ) are added to $200 \mu \mathrm{L}$ yeast cells, previously dispensed. One well is not exposed to any extract as control. Plates are incubated for 3 days. Absorbance and fluorescence signal were measured constantly every $2.5 \mathrm{~h}$.

\subsection{COS-7 Cells Bioassay [15]}

COS-7 cells were grown in Dulbecco's modified eagle medium (DMEM) $1000 \mathrm{mg} / \mathrm{mL}$ glucose, with GlutaMAX and pyruvate (Invitrogen, Carlsbad, CA, USA), supplemented with 10\% fetal bovine serum (FBS) and $1 \%$ non-essential amino acids (NEAA). Cells were maintained at $80 \%-90 \%$ confluence at $37{ }^{\circ} \mathrm{C}$ and $5 \% \mathrm{CO}_{2}$. COS-7 cells in 24-well plates were transiently transfected with pCDNA3-IDO using FuGene HD (Roche Diagnostics, Basel, Switzerland) following manufacturer's instructions. In addition, $3 \mathrm{~h}$ post-transfection, $5 \mu \mathrm{L}$ of samples' stock solutions and $0.1 \times$ diluted solutions were added to cells and incubated for $24 \mathrm{~h}$. Transfection efficiency after $24 \mathrm{~h}$ of extract exposure was assessed by direct observation of enhanced green fluorescent protein (EGFP) signal, using an inverted Carl Zeiss microscope AxioObserver D1 $(\mathrm{Exc}=485 / 20 \mathrm{~nm}, \mathrm{Em}=515 \mathrm{~nm})$ (Oberkochen, Germany). The IDO activity was evaluated by measuring kynurenine concentration in the supernatant by HPLC. Briefly, supernatants from cell culture were collected and immediately frozen at $-20{ }^{\circ} \mathrm{C}$ until analysis. Protein precipitation and kynurenine extraction was performed by addition of trichloroacetic acid (TCA) at a 
final concentration of $6 \%$. After discarding cell debris by centrifugation, supernatants were injected into the HPLC pump (Model LC-6A, Shimadzu Corporation, Kyoto, Japan). Separation was performed using a reversed-phase cartridge Aquasil RP18 column (200 mm length, $4.6 \mu \mathrm{m}$ grain size) from Thermo Scientific (Rockford, IL, USA). An SPD-6AU UV-VIS spectrophotometric detector (Shimadzu Corporation, Kyoto, Japan) in a flow stream series connection was used for detection of kynurenine at a wavelength of $360 \mathrm{~nm}$. The elution buffer consisted of a degassed potassium phosphate solution $(0.015 \mathrm{~mol} / \mathrm{L}, \mathrm{pH} 6.4)$ containing $27 \mathrm{~mL} / \mathrm{L}$ acetonitrile. Analysis was carried out at room temperature at a flow rate of $1.2 \mathrm{~mL} / \mathrm{min}$.

Acknowledgments: This work was financed through the Portuguese Foundation for Science and Technology (Fundação para a Ciência e Tecnologia) within the scope of projects PTDC/QUI-QUI/098053/2008, PEst-OE/QUI/UI0612/2013 and UID/MULTI/00612/2013. The authors thank Madalena Humanes for initiating the Portuguese sponge screening program and for providing the access to her sponge collection.

Author Contributions: Helena Gaspar and Susana Santos designed the experimental procedure, performed the structure elucidation of the compounds and wrote the paper. Adele Cutignano and Angelo Fontana provided the NMR and MS facilities, and helped with the stereo chemical assignment and revision of the manuscript. Joana Xavier collected and identified the sponge material. Helena Gaspar, Vasco Cachatra, Nuno Neng and Laura Grauso carried out the experimental work. BIOALVO's team members (Helena Vieira and Marta Cerejo) conducted the bioassay tests.

Conflicts of Interest: The authors declare no conflict of interest.

\section{References}

1. Chester, M.A. IUPAC-IUB joint commission on biochemical nomenclature (JCBN) nomenclature of glycolipids-Recommendations 1997. Eur. J. Biochem. 1998, 257, 293-298. [PubMed]

2. Barnathan, G.; Couzinet-Mossion, A.; Wielgosz-Collin, G. Glycolipids from Marine Invertebrates. In Outstanding Marine Molecules; Barre, S.L., Kornprobst, J.-M., Eds.; Wiley-Blackwell: Weinheim, Germany, 2014.

3. Warabi, K.; Zimmerman, W.T.; Shen, J.K.; Gauthier, A.; Robertson, M.; Finlay, B.B.; van Soest, R.; Andersen, R.J. Pachymoside A-A novel glycolipid isolated from the marine sponge Pachymatisma johnstonia. Can. J. Chem. 2004, 82, 102-112. [CrossRef]

4. Carballeira, N.M.; Negron, V. Identification and Characterization of 2 New Methylicosadienoic Acids from Erylus-Formosus. J. Nat. Prod. 1991, 54, 305-309. [CrossRef] [PubMed]

5. Carballeira, N.M.; Oyola, D.; Vicente, J.; Rodriguez, A.D. Identification of novel $\alpha$-methoxylated phospholipid fatty acids in the caribbean sponge Erylus goffrilleri. Lipids 2007, 42, 1047-1053. [CrossRef] [PubMed]

6. Sata, N.; Asai, N.; Matsunaga, S.; Fusetani, N. Erylusamines, IL-6 Receptor Antagonists, from the Marine Sponge, Erylus placenta. Tetrahedron 1994, 50, 1105-1110. [CrossRef]

7. Fusetani, N.; Sata, N.; Asai, N.; Matsunaga, S. Isolation and Structure Elucidation of Erylusamine-B, a New Class of Marine Natural-Products, Which Blocked an IL-6 Receptor, from the Marine Sponge Erylus placenta Thiele. Tetrahedron Lett. 1993, 34, 4067-4070. [CrossRef]

8. Goobes, R.; Rudi, A.; Kashman, Y.; Ilan, M.; Loya, Y. Three new glycolipids from a Red Sea sponge of the genus Erylus. Tetrahedron 1996, 52, 7921-7928. [CrossRef]

9. Van Altena, I.; van Soest, R.; Roberge, M.; Andersen, R.J. Trisphaerolide A, a novel polyketide from the Dominican sponge Erylus trisphaerus. J. Nat. Prod. 2003, 66, 561-563. [CrossRef] [PubMed]

10. Malachowski, W.P.; Winters, M.; DuHadaway, J.B.; Lewis-Ballester, A.; Badir, S.; Wai, J.; Rahman, M.; Sheikh, E.; LaLonde, J.M.; Yeh, S.R.; et al. O-alkylhydroxylamines as rationally-designed mechanism-based inhibitors of indoleamine 2,3-dioxygenase-1. Eur. J. Med. Chem. 2016, 108, 564-576. [CrossRef] [PubMed]

11. Peng, Y.H.; Ueng, S.H.; Tseng, C.T.; Hung, M.S.; Song, J.S.; Wu, J.S.; Liao, F.Y.; Fan, Y.S.; Wu, M.H.; Hsiao, W.C.; et al. Important Hydrogen Bond Networks in Indoleamine 2,3-Dioxygenase 1 (IDO1) Inhibitor Design Revealed by Crystal Structures of Imidazoleisoindole Derivatives with IDO1. J. Med. Chem. 2016, 59, 282-293. [CrossRef] [PubMed]

12. Rohrig, U.F.; Majjigapu, S.R.; Vogel, P.; Zoete, V.; Michiein, O. Challenges in the Discovery of Indoleamine 2,3-Dioxygenase 1 (IDO1) Inhibitors. J. Med. Chem. 2015, 58, 9421-9437. [CrossRef] [PubMed] 
13. National Cancer Institute. Available online: http://www.cancer.gov/about-cancer/treatment/clinicaltrials/search/results?protocolsearchid=14884282 (accessed on 15 April 2016).

14. Austin, C.J.; Kahlert, J.; Issa, F.; Reed, J.H.; Smith, J.R.; Ioppolo, J.A.; Ong, J.A.; Jamie, J.F.; Hibbs, D.; Rendina, L.M. The first indoleamine-2,3-dioxygenase-1 (IDO1) inhibitors containing carborane. Dalton Trans. 2014, 43, 10719-10724. [CrossRef] [PubMed]

15. Cerejo, M.; Andrade, G.; Roca, C.; Sousa, J.; Rodrigues, C.; Pinheiro, R.; Chatterjee, S.; Vieira, H.; Calado, P. A Powerful Yeast-Based Screening Assay for the Identification of Inhibitors of Indoleamine 2,3-Dioxygenase. J. Biomol. Screen. 2012, 17, 1362-1371. [CrossRef] [PubMed]

16. Doco, T.; O'Neill, M.A.; Pellerin, P. Determination of the neutral and acidic glycosyl-residue compositions of plant polysaccharides by GC-EI-MS analysis of the trimethylsilyl methyl glycoside derivatives. Carbohyd. Polym. 2001, 46, 249-259. [CrossRef]

17. Clayden, J.; Johnson, P.; Pink, J.H.; Helliwell, M. Atropisomeric amides as chiral ligands: Using (-)-sparteine-directed enantioselective silylation to control the conformation of a stereogenic axis. J. Org. Chem. 2000, 65, 7033-7040. [CrossRef] [PubMed]

18. Shih, F.Y.; Chen, T.H.; Lu, M.C.; Chen, W.F.; Wen, Z.H.; Kuo, Y.H.; Sung, P.J. Cladieunicellins K and L, New Eunicellin-Based Diterpenoids from an Octocoral Cladiella sp. Int. J. Mol. Sci. 2013, 14, 21781-21789. [CrossRef] [PubMed]

19. Wojnar, J.M.; Northcote, P.T. The Agminosides: Naturally Acetylated Glycolipids from the New Zealand Marine Sponge Raspailia agminata. J. Nat. Prod. 2011, 74, 69-73. [CrossRef] [PubMed]

20. Peddie, V.; Takada, K.; Okuda, S.; Ise, Y.; Morii, Y.; Yamawaki, N.; Takatani, T.; Arakawa, O.; Okada, S.; Matsunaga, S. Cytotoxic Glycosylated Fatty Acid Amides from a Stelletta sp. Marine Sponge. J. Nat. Prod. 2015, 78, 2808-2813. [CrossRef] [PubMed]

21. Molinski, T.F.; Morinaka, B.I. Integrated approaches to the configurational assignment of marine natural products. Tetrahedron 2012, 68, 9307-9343. [CrossRef] [PubMed]

22. Cutignano, A.; Nuzzo, G.; D’Angelo, D.; Borbone, E.; Fusco, A.; Fontana, A. Mycalol: A natural lipid with promising cytotoxic properties against human anaplastic thyroid carcinoma cells. Angew. Chem. 2013, 52, 9256-9260. [CrossRef] [PubMed]

23. Solladié, G.; Hanquet, G.; Rolland, C. Stereoselective Sulfoxide Directed Reduction of 1,2-Diketo-Derivatives to Enantiomerically Pure Syn and Anti 1,2-Diols. Tetrahedron Lett. 1997, 38, 5847-5850. [CrossRef]

24. Bubb, W.A. NMR spectroscopy in the study of carbohydrates: Characterizing the structural complexity. Concepts Magn. Reson. A 2003, 19, 1-19. [CrossRef]

25. Beier, R.C.; Mundy, B.P.; Strobel, G.A. Assignment of Anomeric Configuration and Identification of Carbohydrate Residues by C-13 Nmr. 1. Galactopyranosides and Glucopyranosides and Furanosides. Can. J. Chem. 1980, 58, 2800-2804. [CrossRef]

26. Shin, J.; Lee, H.S.; Woo, L.; Rho, J.R.; Seo, Y.; Cho, K.W.; Sim, C.J. New triterpenoid saponins from the sponge Erylus nobilis. J. Nat. Prod. 2001, 64, 767-771. [CrossRef] [PubMed]

(C) 2016 by the authors; licensee MDPI, Basel, Switzerland. This article is an open access article distributed under the terms and conditions of the Creative Commons Attribution (CC-BY) license (http://creativecommons.org/licenses/by/4.0/). 